\title{
Geology of the Cypress Hills
}

By JOHN HOWARD HUDSON, Regina

The most casual visitor to the Cypress Hills of Saskatchewan must scme imes wonder what these highlands are made of, and how they cam to be. I shall attempt briefly to present the findings of geologists in this intriguing area.

Let us first look at a simple geologic column of the formations (roc) layers) out of which the Hills are carved.

\begin{tabular}{|c|c|c|c|c|}
\hline Formation & Thickness, in feet & Composition & Geologic Period & Time, years ago \\
\hline Glacial Drift & $\begin{array}{l}0-200(?) \\
\text { Generally scanty }\end{array}$ & $\begin{array}{l}\text { Mixture of clay, sand } \\
\text { and boulders }\end{array}$ & Pleistocene & $25,000-1,000,000$ \\
\hline Cypress Hills & $300-550$ & $\begin{array}{l}\text { Mostly hard conglom- } \\
\text { erate-quartzite cobbles } \\
\text { mixed with sand and } \\
\text { cemented }\end{array}$ & Oligocene & About $30,000,00$ \\
\hline Ravenscrag & $\begin{array}{l}0-230, \text { generally } \\
\text { about } 200\end{array}$ & $\begin{array}{l}\text { Mostly yellowish silt, } \\
\text { some grey clay, and } \\
\text { coal }\end{array}$ & Paleocene & $\begin{array}{l}60,000,000 \\
70,000,000\end{array}$ \\
\hline Frenchman & $\begin{array}{l}10-200 \\
\text { generally } 60-80\end{array}$ & $\begin{array}{l}\text { Some yellow sand- } \\
\text { stone, much grey clay, } \\
\text { no coal }\end{array}$ & Upper Cretaceous & $\begin{array}{l}70,000,000- \\
100,000,000\end{array}$ \\
\hline Battle & $0-40$, usually $15-25$ & Black clay & Upper Cretaceous & $\begin{array}{l}70,000,000 \\
100,000,000\end{array}$ \\
\hline Whitemud & $50-75$ & Chalky white clay & Upper Cretaceous & $\begin{array}{l}70,000,000 \\
100,000,000\end{array}$ \\
\hline Eastend & About 70 & $\begin{array}{l}\text { Grey sand; much grey } \\
\text { clay }\end{array}$ & Upper Cretaceous & $\begin{array}{l}70,000,000 \\
100,000,000\end{array}$ \\
\hline Bearpaw & $900-1000$ & Sterile grey clay & Upper Cretaceous & $\begin{array}{l}70,000,000 \\
100,000,000\end{array}$ \\
\hline
\end{tabular}

These formations are poorly exposed in the Park and elsewhere along the north side of the hills, owing to a heavy coating of glacial drift. For good exposures, one must go to the southern slopes, especially the valley of the Frenchman river around Eastend. Ravenscrag Butte, on the north side of the river between Eastend and Ravenscrag, exhibits these strata in most impressive cliffs.

The geologic history begins, for the purposes of this discussion, with a great Upper Cretaceous sea depositing the Bearpaw shale. This sea withdrew eastward; more exactly, the land rose, starting at the west. The sands of the Eastend formation mark the changes from shallow sea to low land built up at river mouths. T Whitemud, Battle, Frenchman, a Ravenscrag formations are all no marine, laid down on land by rive draining down from the rising Roc Mountains. The Whitemud (which mined for ceramic clay at Easten carries fossil leaves of hardwood tre Fossils of horned dinosaurs, amc: the last of their race, have be 1 collected from the Frenchman ald? Conglomerate Creek northwest f Eastend. The coal of the Ravensc: s indicates moist flats thickly cove: $x$ with mixed forest; apparently $t$ much uplift was going on just th 1 . Later on renewed uplift caused e rivers to cut down and erode se $m \in n t$, rather than deposit it; and o $r$ 
most all of Southern Saskatchewan plift and erosion have continued, iterrupted by the Ice Age, until the resent day.

In the Cypress Hills region matters ok a somewhat different turn. bout Oligocene time there must ave been a fairly sudden uplift in he Rocky Mountains; one or more vers were able to carry pretty fair zed cobbles (up to eight inches cross) of hard quartzite down from he mountains and deposit them upon he plains. This is the origin of the ypress Hills conglomerate, that hard yer which now caps the hills. This ver-iaid conglomerate most likely nce. extended much further north nd south than it does now. It has een eroded away by rivers except top the Cypress Hills; they stand ecause this is where the divide beween north and south flowing river wstem happened to be before the ce Age. The height and steepness the slopes comes about because ne hard layer overlies a great thickess of soft rocks. If a river cuts hrough such a hard layer, the soft yer all waste speedily away; but he soft layers cannot be attacked ntil the hard layer is cut through. emphasize that the Cypress Hills re not uplifted folded mountains ke the Bearpaw Mountains 60 miles the south; geological reports dissree about the position and even he existence of faint folds in the tills.

The last major event in the geopgic history of the Cypress Hills was ie Ice Age. The great ice sheets ming from the northeast had lost lot of pep by the time they arrived ere. There are no glacial deposits Dove 4500 feet (that is, in that part $f$ the West Block west of Battle (reek); and on most of the rest of he plateau, or Main Bench, the odd rratic (limestone or granite boulder) here and there make up the evidence for the presence of continental ice. During most of the Ice Age the edge of the ice sheet lay up against the norih face of the plateau, depositing morainic debris there. The south side was only rarely iced over, and what ice was present was present seems largely to have flowed around the east end, by way of Dollard. The chief result of the Ice Age in the Cypress Hills was that, since the ice iay to north, the south-flowing rivers were able to cut their valleys headward right up to the ice front, almost across the hills-Belanger Creek in the Park is a fine example.

For those who wish to pursue the subject further the following reports (from which much of this has been cribbed) may be of interest.

\section{COLOURED PRINTS OF MUSEUM HABITAT CASES}

The Regina Natural History Society has for sale coloured prints of Museum habitat cases. These are the reproductions that have been used for covers for the Saskatch€wan Teachers' Federation Bulletin. Size 6" $\times 10$ ", with short descriptive text. Price: 15c per print, or $\$ 1.25$ per set of seven in special envelope. Subjects: Whooping Crane, Pelican and Cormorant, Great Blue Heron, Beaver, Wolf, White-tailed Deer, "Bambi".

Write:

MRS. MARIE ROBINSON Secretary, Regina Natural History Society

2100 York St., Regina

YPRESS LAKE MAP-AREA, by G. M. Furnival. Geol. Surv. Canada Memoir 242. Queen's Printer, Ottawa, 1946.

FELOGY OF EASTERN CYPRESS HILLS, by W. O. Kupsch. Sask. Geol. Survey Report No. 20. Queen's Printer, Regina, 1956.

EOLOGY OF SOUTHERN SASKATCHEWAN, by Fraser, McLearn, Russell, Warren, and Wickenden. Geol. Surv. Canada Memoir 176. Queen's Printer, Ottawa, 1935.

PEOLOGY OF THE SOUTHERN PART OF THE CYPRESS HILLS, by L. S. Russell. Sask. Geol. Survey Report No. 8. Queen's Printer, Regina, 1948. 